\title{
Management of Banana Pseudostem Weevil - A Biological Approach
}

\author{
Debanand Das $^{1,2^{*}}$, Nibedita Borgohain ${ }^{2}$, Ashok Bhattacharyya ${ }^{3}$ and Kartik Baruah ${ }^{4}$ \\ ${ }^{1}$ AICRP on Fruits, ${ }^{2}$ Department of Nematology, ${ }^{3}$ Director of Research (Agri.), ${ }^{4}$ Department of \\ Horticulture, Assam Agricultural University, Jorhat-13, India \\ *Corresponding author
}

\begin{tabular}{|l|}
\hline Ke y w or d s \\
Banana pseudostem \\
weevil, Beauveria \\
bassiana, \\
$\begin{array}{l}\text { Heterorhabditis } \\
\text { indica }\end{array}$ \\
\hline Article Info \\
\hline $\begin{array}{l}\text { Accepted: } \\
\text { 17 September } 2019 \\
\text { Available Online: } \\
\text { 10 October } 2019\end{array}$ \\
\hline
\end{tabular}

A B S T R A C T
The production and productivity of banana is governed by many biotic and abiotic factors. Among biotic factors, incidence of insect-pests is considered as one of the major hindrance in successful cultivation of banana. In India, about eight pests commonly infest the banana crops; but of these, the banana stem weevil (Odoiporus longicollis) is cosmopolite's insect pest that threatens the banana cultivation. The most common management practices followed for managing this pest includes cultural practices and application of insecticides. An attempt was made to manage this insect pest using biocontrol agents with the following treatments: Beauveria bassiana $\left(1 \times 10^{7}\right.$ spores $\left./ \mathrm{ml}\right)$ spray at $5^{\text {th }}, 6^{\text {th }}$ and $7^{\text {th }}$ months after planting; Metarrhizium anisopliae $\left(1 \times 10^{7}\right.$ spores $\left./ \mathrm{ml}\right)$ spray at $5^{\text {th }}, 6^{\text {th }}$ and $7^{\text {th }}$ months after planting; swabbing $B$. bassiana on the pseudostem at 5, 6 and7 month after planting; swabbing $M$. anisopliae on the pseudostem at 5, 6 and 7 month after planting; Heterorhabditis indica spray at 5, 6, 7 month after planting; stem trap swapped with $B$. bassiana@10ml/trap at 5 month after planting; stem trap swapped with $H$. indica@ $1 \times 10^{9} \mathrm{IJS} / \mathrm{ml}$ at 5 th month after planting; insecticidal check - chlorpyrifos $(0.1 \%)$ and untreated Control. Three years of experimentation resulted that among the bio-agents, application of $B$. bassiana was found to be the most effective in reducing the population of banana stem weevil. Amongst the treatments, swabbing B. bassiana on the pseudostem at 5,6 and 7 month after planting showed the best result followed by stem trapping of banana stem weevil swapped with B.bassiana @ 10ml/trap at 5 month after planting. There was 59.31 and 69.78 per cent reduction in psuedostem infestation over control at 7 months after planting and at harvest, respectively in the best treatment. However, insecticidal spray out yielded all the treatment in reducing the pest incidence and increasing the yield of banana.

\section{Introduction}

Banana is the fourth most important crops in the developing world after rice, wheat and corn, and is cultivated in about 130 countries that lay in tropical and subtropical regions
(Anon, 2000). India is the world's largest producer of bananas and plantains, however, production and productivity of banana is largely influenced by the attack of insect pests. In India, banana corm weevil, Cosmopolites sordidus (Germar) and the banana pseudostem 
borer, Odoiporus longicollis (Oliver) are considered as the major pests (Valmayor et al., 1994; Gold et al., 1999; Sripriya et al., 2000; Padmanaban and Kandasamy, 2003) out of about 15 commonly occurring insect pests that infest the banana crop.

The monophagus banana pseudostem borer is commonly found in India, China, Malaysia, Indonesia, Nepal and Thailand and severely affects the production and productivity of banana in these countries (Visalakshi et al., 1989, Valmayor et al., 1994). The larvae make tunnels by feeding voraciously on the tissues of the succulent sheath and reach the true stem. Due to the tunneling activity of the larvae, the stem rots and falls down due to loss of tensile strength (Padmanaban and Sathiamoorthy, 2001). These tunnels also act as an infection court for many rot promoting organisms (Gold et al., 2001). A yield loss ranging from 10-90 per cent has been reported depending on the stage of plant growth at which pest infestation occurs and also the efficiency of the management or cultivation practice followed (Padmanaban and Sathiamoorthy, 2001). Banana pseudostem is a common insect pest of banana in Assam.

All most all AAA banana genotypes are found to be susceptible to this pest (Das and Baruah, 2018). Monocropping for several years associated with poor management practices tremendously increases its infestation. The most common management practices followed for managing this pest includes cultural practices and application of insecticides. Application of chemical insecticides though the most effective method for managing this pest, but it poses threat to the environment causing air - ground water pollution and health hazards. Considering the importance of the problem and ill consequences of use of chemical insecticides, a field trial was conducted for management of banana pseudostem borer using biological agents.

\section{Materials and Methods}

Field experiment was conducted at the Horticultural Orchard, Assam Agricultural University, Jorhat -13 during 2010-2015 in a naturally infested field with banana pseudostem weevil, Odoiporus longicollis. The experiment was laid in randomized block design with nine treatments, each with three replications. The treatments included were: $\mathrm{T}_{1}$ : Beauveria bassiana $\left(1 \times 10^{7}\right.$ spores/ml) spray at $5^{\text {th }}, 6^{\text {th }}$ and $7^{\text {th }}$ months after planting, $\mathrm{T}_{2}$ : Metarrhizium anisopliae $\left(1 \times 10^{7}\right.$ spores $\left./ \mathrm{ml}\right)$ spray at $5^{\text {th }}, 6^{\text {th }}$ and $7^{\text {th }}$ months after planting, $\mathrm{T}_{3}$ : swabbing $B$. bassiana $\left(1 \times 10^{7}\right.$ spores $\left./ \mathrm{ml}\right)$ on the pseudostem at 5, 6 and7 month after planting, $\mathrm{T}_{4}$ : swabbing $M$. anisopliae $\left(1 \times 10^{7}\right.$ spores $/ \mathrm{ml}$ ) on the pseudostem at 5, 6 and7 month after planting, $\mathrm{T}_{5}$ : Heterorhabditis indica spray at 5, 6, 7 month after planting, $\mathrm{T}_{6}$ : stem trap swapped with B. bassiana @ $10 \mathrm{ml} /$ trap at 5 month after planting, $\mathrm{T}_{7}$ : stem trap swapped with $H$. indica @ 1 1 10 $10^{9} \mathrm{IJS} / \mathrm{ml}$ at 5th month after planting, $\mathrm{T}_{8}$ : insecticidal check - chlorpyrifos @0.1\% (2.5 ml/lit) and $\mathrm{T}_{9}$ : untreated Control. Banana cultivar 'Jahaji' (susceptible to banana pseudostem weevil) was planted at a spacing of $1.5 \times 1.5 \mathrm{~m}$ with eight plants per treatment.

The crop was raised in rainfed condition and all crop management activities were carried out as per package. Observations on per cent pseudostem infestation at 7 months after planting and at harvest and yield parameters were recorded.

For stem trapping, pseudostem of susceptible banana cultivar was longitudinally splited in to two halves and then cut into about $2.0 \mathrm{ft}$ pieces. Each single piece was treated with required quantity of biocontrol agents.

One such trap was used for an area of $2.25 \mathrm{~m}^{2}$. The traps were changed at weekly interval with a fresh trap. 


\section{Results and Discussion}

Three years pooled data presented in Table 1 reflects that all the treatments significantly reduced the infestation of banana pseudostem weevil and increased plant growth parameters and yield of banana cv. 'Jahaji'. Amongst the treatments with biocontrol agents, swabbing Beauveria bassiana $\left(1 \times 10^{7}\right.$ spores $\left./ \mathrm{ml}\right)$ on the pseudostem at 5, 6 and 7 months after planting $\left(T_{3}\right)$ exhibited the best result in reducing the weevil infestation and increasing plant growth parameters and yield.

Among the treatments with biocontrol agents, maximum plant growth $(113.10 \mathrm{~cm})$ at harvest was recorded at $\mathrm{T}_{3}$ i.e. swabbing $B$. bassiana on the pseudostem at 5,6 and7 months after planting. There was 4.32 per cent increase in plant growth over untreated control. Treatment with swabbing Metarrhizium anisopliae on the pseudostem at 5, 6 and7 month after planting $\left(\mathrm{T}_{4}\right)$, Heterorhabditis indica spray at 5, 6, 7 month after planting $\left(\mathrm{T}_{5}\right)$, stem trap swapped with B. bassiana @ 10ml/trap at 5 month after planting $\left(\mathrm{T}_{6}\right)$ and stem trap swapped with $H$. indica@1 @ $10^{9} \mathrm{IJS} / \mathrm{ml}$ at 5 th MAP $\left(\mathrm{T}_{7}\right)$ were at par with the treatment $T_{3}$ in respect to plant height. Similarly, plant girth at harvest also was maximum at this treatment $\left(\mathrm{T}_{3}\right)$. A significant of 8.66 per cent in increase in plant girth was recorded at this treatment over untreated control. This treatment was followed by stem trap swapped with B. bassiana @ $10 \mathrm{ml} /$ trap at 5 month after planting $\left(\mathrm{T}_{6}\right)$, and was at par with $\mathrm{T}_{3}$ (Table 1).

Lowest number of pseudostem infested plants at 7 months after planting and at harvest was recorded with swabbing $B$. bassiana on the pseudostem at 5, 6 and 7 month after planting $\left(\mathrm{T}_{3}\right)$, followed by stem trap swapped with $B$. bassiana@10ml/trap at 5 month after planting $\left(\mathrm{T}_{6}\right)$. There was 59.31 and 69.78 per cent reduction in psuedostem infestation over control at 7 months after planting and at harvest, respectively; when banana psuedostem were swabbed with B. bassiana at 5, 6 and 7 month after planting (Table 1).

Swabbing B. bassiana on the pseudostem at 5, 6 and7 months after planting significantly increased the yield and yield attributing parameters of banana over untreated control.

Maximum length of the finger, girth of the finger, number of hands per bunch and yield was recorded in this treatment than other bioagents treatment.

Use of entomopathogenic fungi had been reported with success for combating the infestation of banana weevils since 1970s (Ayala \& Monzon 1977; Delattre \& Jean-Bart 1978). Amongst the entomopathogenic fungi, Beauveria bassiana and Metarhizium anisopliae were found to be more promising in reducing the weevil population (Mesquita $e t$ al.,1981; Pena et al., 1995). Wang and Yen (1972) reported that banana pseudostem weevils were highly susceptible to the entomogenous fungus, Metarhizium anisopliae. M. anisopliae affected more than 90 per cent mortality under laboratory conditions.

Ferron (1981) stated that B. bassiana and $M$. anisopliae gained considerable attention as biological control agents for controlling cryptic insects, such as banana weevil, which were difficultly accessible to arthropod natural enemies. Padmanaban and Sathiamoorthy (2001) isolated a good number of fungal pathogens viz., Fusarium solani, Mucor heimalis, Aspergillus niger and Scopulariopsis bevicaulis from field population of $O$. longicollis, which may be effective in managing this pest. Padmanaban et al., (2009) observed highest reduction of weevil infestation when stem traps were swabbed with rice chaffy grain formulation of $B$. bassiana. 
Table.1 Effect of different biocontrol agents on management of banana pesudostem weevil (Mean of three years)

\begin{tabular}{|c|c|c|c|c|c|c|c|c|}
\hline Treatments & $\begin{array}{c}\text { Plant } \\
\text { height at } \\
\text { harvest } \\
(\mathrm{cm})\end{array}$ & $\begin{array}{c}\text { Plant } \\
\text { girth at } \\
\text { harvest } \\
(\mathrm{cm})\end{array}$ & $\begin{array}{c}\begin{array}{c}\text { Number } \\
\text { of plant } \\
\text { infested } \\
(\%)\end{array} \\
\text { After } 7 \\
\text { months }\end{array}$ & $\begin{array}{c}\text { Intensity of } \\
\text { infestation } \\
\text { at } \\
\text { harvesting } \\
\text { stage }\end{array}$ & $\begin{array}{c}\text { Length } \\
\text { of } \\
\text { finger } \\
(\mathrm{cm})\end{array}$ & $\begin{array}{l}\text { Girth of } \\
\text { finger } \\
(\mathrm{cm})\end{array}$ & $\begin{array}{l}\text { No of } \\
\text { hands/ } \\
\text { bunch }\end{array}$ & $\begin{array}{c}\text { Yield (kg } \\
\text { /plant) }\end{array}$ \\
\hline $\mathbf{T}_{1}$ & 108.77 & 70.75 & 32.09 & 34.40 & 15.36 & 8.82 & 8.7 & 12.53 \\
\hline $\mathbf{T}_{2}$ & 109.57 & 69.83 & 34.01 & 39.87 & 15.50 & 8.61 & 8.1 & 12.03 \\
\hline $\mathbf{T}_{3}$ & 113.10 & 75.25 & 25.04 & 31.63 & 15.70 & 9.32 & 9.7 & 14.40 \\
\hline $\mathbf{T}_{4}$ & 111.87 & 69.50 & 33.56 & 38.07 & 15.82 & 9.14 & 8.5 & 12.06 \\
\hline $\mathbf{T}_{5}$ & 110.40 & 70.08 & 35.15 & 45.30 & 15.03 & 8.37 & 7.1 & 11.18 \\
\hline $\mathbf{T}_{6}$ & 111.13 & 72.08 & 28.45 & 35.67 & 15.52 & 8.94 & 8.7 & 13.00 \\
\hline $\mathbf{T}_{7}$ & 112.90 & 70.42 & 33.21 & 36.37 & 15.52 & 8.46 & 7.5 & 11.73 \\
\hline $\mathbf{T}_{8}$ & 115.08 & 75.50 & 15.49 & 19.83 & 16.03 & 9.97 & 11.4 & 16.55 \\
\hline $\mathbf{T}_{9}$ & 108.42 & 69.25 & 39.89 & 53.70 & 10.07 & 6.90 & 7.1 & 9.13 \\
\hline CD $(0.05)$ & 2.91 & 4.30 & 2.48 & 5.71 & 0.96 & 0.57 & 0.56 & 0.73 \\
\hline
\end{tabular}

They concluded that B. bassiana (isolate: $17-$ 6) has potential as a biocontrol agent to manage pseudostem weevils of banana. Irulandi et al., (2012) reported that stem trapping with $B$. bassiana could cause 56.75 per cent reduction of banana pseudostem weevil. In a laboratory study, Alagesan et al., (2019) observed that B. bassiana isolate KH3 $\left(1 \times 10^{8}\right.$ conidia/ $\left.\mathrm{mL}^{-1}\right)$ was more bioeffective against $O$. longicollis larvae, causing $>90 \%$ significant mortality in 12 and 18 days. The present study also is in agreement with the observation of the above authors and concludes that stem trapping with Beauveria bassiana can be effectively used for management of banana pseudostem weevil.

\section{References}

Anonymous. 2000. Food and Agricultural Organization, year book, 2000.

Alagesan, A., Padmanaban, B., Tharani, G., Jawahar, S. and Manivannan, S. 2019. An assessment of biological control of the banana pseudostem weevil Odoiporus longicollis (Olivier) by entomopathogenic fungi Beauveria bassiana. Biocatalyst and Agricultural Biotechnology 20: 101262

Ayala, J. L. and Monzon, S. 1977. Ensayo sobre diferentes dosis de Beauveria bassiana para el control del picudo negro del platano (Cosmopolites sordidus) (Germar). Centro Agric., Rev. Cien. de Fac. Cienc. Agric. 4: 1924

Das, D. and Baruah, K. 2018. Reaction of banana cultivars against banana pseudostem borer and leaf and fruit scarring beetle. Indian J. Entomon. 80:1148-1150.

Ferron, P. 1981. Colonization by the fungi Beauveria and Metarhizium. In H.D. Burges (ed) Microbial Control of Pests and Plant Diseases, 1970-1980, pp. 456-82. New York: Academic Press.

Irulandi, S., Eraivan A. A. K. and Srivara Buddhi Bhuvaneswari, S. 2012. Assessment of biopesticides and insecticide against pseudostem weevil Odoiporus longicollis Oliver in red banana J. Biopest, 5 (Supplementary): 68-71

Padmanaban, B. and Kandasamy, M. 2003. 
Survival of banana weevil borers in banana plant residues. Indian $J$. Entomon 65 (3): 424-425

Padmanaban, B., and Sathiamoorthy, S. 2001. Banana stem weevil, Odoiporus longicollis. Musa Pest Fact Sheet No.5, INIBAP, France.

Padmanaban, B., Thangavelu, R., Gopi, M. and Mustaffa, M. M. 2009. Effect of mass multiplication media on sporulation, field efficacy and shelf life of Beauveria bassiana against rhizome and pseudostem weevils of banana. $J$. Biol. Control, 23: 277-283.

Pena, J. E., Gilbin-Davis, R. M. and Duncan, R. 1995. Impact of indigenous Beauveria bassiana (Balsamo) Vuillemin on banana weevil and rotten sugarcane weevil (Coleoptera: Curculionodae) populations in banana in Florida. Journal of Agricultural Entomology, 12: 163-167.

Sripriya, C., Padmanaban, B. and Uma, S. 2000. Evaluation of banana (Musa sp.) germplasm against insect pests. Indian J. Entomon. 62: 382-390.

Valmayor, R. V., Davide, R. G., Stanton, J.
M., Treverrow, N. L. and Rao, V. N. 1994. Banana nematodes and weevil borers in Asia and Pacific. Proceedings of a conference workshop: INIBAP/ ASPNET, Los Banos, Philippines, 258 pp.

Gold, C.S., Rukazambuga, N. D. T. M., Karamura, E. B., Nemeye, P. and Night, G. 1999. Recent advances in banana weevil borer, population dynamics and pest status with emphasis on east Africa. In: Mobilizing IPM for sustainable banana production in Africa. Proc. Workshop on banana IPM held in Nelspruit S. Africa 20-22 November, 1998. INIBAP, France.

Visalakshi, A., Nair, G. M., Beevi, S. N. and Amma, A. M. K. 1989. Occurrence of Odoiporus longicollis Oliver (Coleoptera: Curculionidae) as a pest of banana in Kerala. Entomon. 14:367368.

Wang. B.T. and Yen. D.F.1972. Memoirs of the College of Agriculture National Taiwan University, 13: 31-46

\section{How to cite this article:}

Debanand Das, Nibedita Borgohain, Ashok Bhattacharyya and Kartik Baruah. 2019. Management of Banana Pseudostem Weevil - A Biological Approach. Int.J.Curr.Microbiol.App.Sci. 8(10): 2270-2274. doi: https://doi.org/10.20546/ijcmas.2019.810.263 